\title{
MULTI-LEVEL ENVIRONMENTAL GOVERNANCE: THE CASE OF WIND POWER DEVELOPMENT IN SWEDEN
}

\author{
Stefan Larsson \\ Lund University Internet Institute \\ Blekinge Institute of Technology, Sweden \\ Stefan.Larsson@luii.lu.se \\ Lars Emmelin \\ Lars.Emmelin@bth.se \\ Sandra Vindelstam \\ Lund University Internet Institute, Sweden \\ Received on 5 March 2014; accepted on 20 June 2014
}

doi:10.13165/SMS-14-6-2-04

\begin{abstract}
At national policy level in Sweden, the importance of development of wind power is emphasized. However, the actual implementation is highly dependent on local permit giving for windmills. The legislation governing the permit giving has been revised in an attempt to make the local processes faster and to shift the permit process towards a more regional environmental process as opposed to a more plan-based municipal process. By tradition in Sweden, the local, municipal level has had a strong mandate in land use planning which is often referred to as the "the municipal planning monopoly", which means that there is a tension whenever a legal proposal seeks to diminish this "plan monopoly". The legal investigation suggesting changes in the law on permit-giving stressed the need for strengthening the regional assessment, which led to a compromise called the "municipal veto-right", where the regional environmental permit
\end{abstract}


needs a formal approval from the municipality for the permit process to continue. This study investigates both the legal development of the so-called veto-right as well as what it empirically has led to, and how it is perceived by the industry as well as concerned parties. For this reason, a sample of 30 regional permit cases has been collected, and a limited number of interviews have been conducted with judges in appeal courts and regional handling officers assessing turbine applications. The results indicate that the industry sees the "veto" as leading to problematic uncertainty in the process at regional level and, therefore, prefer to keep the applications at a level that entitles them to use the municipal permit system which is determined by height and number of turbines. This is a consequence directly opposite to what the legal commission aimed for when revising the legal system.

Keywords: wind power, law, spatial planning, tiering, multi-level governance, municipal veto.

\section{Introduction}

This study represents an interdisciplinary enterprise to study a case of relevance for environmental policy, management and planning when it comes to issues of tiering, and power between different levels in environmental governance. It is argued here that it is necessary for environmentally relevant planning for renewable energy technologies to understand more the challenges inherent in the multilevelled governance of spatial planning, in this case exemplified by Swedish wind power development. For example, the dialogue between stakeholders is to a large extent determined by the legal setting in which they operate. Within a framework of rational decision-making, a common conception of strategic decision-making is one of a hierarchical system with an increasing level of detail as one moves down to implementation and daily operation ${ }^{1}$.

Wind power development in Sweden is interesting not least because it can serve as illustration of two sets of problems in environmental governance and spatial planning ${ }^{2}$. Implementing national goals for renewable energy faces both the problems

1 Alexander, E.R. 2000. Rationality Revisited: Planning Paradigms in a Post-Postmodernist Perspective. Journal of Planning Education and Research. 19: 242-256. Marks, G.; Hooghe, L. 2004. Contrasting Visions of Multi-Level Governance. In: Bache \& Flinders (Eds.). MultiLevel Governance. Oxford: Oxford University Press.Sager, 1994; cf Larsson, S. 2008. Between Daring and Deliberating - 3G as a Sustainability Issue in Swedish Spatial Planning. Blekinge Institute of Technology, Licentiate Dissertation Series No. 2008:02, School of Technoculture, Humanities and Planning.

2 Larsson, S. 2009. Problematisering av vindkraftens regelverk. En pilotstudie. Forskningsrapport Nr. 2009:04, Rapport nr 7 från MiSt-programmet, Blekinge Tekniska Högskola, ISSN 11031581. Larsson, S. 2011b. Vindkraftsutbyggnaden - Vem bestämmer och baserat på vilken kunskap? In: Mossberg (ed.). Buller i blåsväder - texter om ljud från vindkraftverk. Skrifter från Ljudmiljöcentrum vid Lunds universitet Rapport nr 11. 
of multi-level governance and the special conditions imposed by the existence of two parallel systems of planning and permit granting, including demands for participation and efficiency ${ }^{3}$. In Sweden, the obstacle to an increased reliance on wind energy is often said to be slow and complicated wind power planning and permit procedures with local opposition playing an important role 4 . Thus, when the main Swedish legislation concerning wind power development was revised in 2009, it was done with the goal of making the processes more efficient from the point of view of national goals and developers 5 . This has resulted in two different combinations of environmental permit granting and spatial planning of wind power deployment.

More specifically, wind power development in Sweden to a large extent relies on two different sets of legislation - the Planning and Building Act, the PBA, and the Environmental Code, the EC. It has been argued that they codify two types of paradigms or cultures concerning what constitutes the basis for legitimate decisions ${ }^{6}$. These have been argued to be of importance to understand the outcome of decision-making under these two sets of regulations, for example, concerning issues of public participation in the development of the infrastructure for the third generation of mobile telephony in Sweden ${ }^{7}$. To facilitate the development of wind power, in 2007 the Swedish Government appointed a committee with the mandate to investigate how the permitting process for wind energy could become more efficient ${ }^{8}$. The legal investigation had to choose between either the "municipal spatial

3 cf. Newig, J.; Fritsch, O. 2009. Environmental Governance: Participatory, Multi-level - and Effective? Environmental Policy and Governance. 19(3): 197-214.

4 Bergek, A.; Jacobsson, S. 2003. The Emergence of a Growth Industry: A Comparative Analysis of the German, Dutch and Swedish Wind Turbine Industries. In: Metcalfe, J.S., Cantner, U. (Eds.). Change, Transformation and Development. Physica-Verlag, Heidelberg, p. 197227. Michanek, G.; Söderholm, P. 2006. Medvind i uppförsbacke. En studie av den svenska vindkraftspolitiken. Report to the Expert Group for Environmental Studies, Swedish Ministry of Finance, Stockholm. Åstrand, K.; Neij, L. 2006. An Assessment of Governmental Wind Power Programmes in Sweden - Using a Systems Approach. Energy Policy. 34: 277-296. Preparatory legal report SOU 2008:86 Prövning av vindkraft, delbetänkande av Miljöprocessutredningen, Stockholm. Prop. 2008/09: 146, Prövning av vindkraft, Miljödepartementet.

6 Emmelin, L.; Kleven, T. 1999. A Paradigm of Environmental Bureaucracy? Attitudes, Thought Styles, and World Views in the Norwegian Environmental Administration. NIBR's Pluss Series, p. 5-99. Emmelin, L.; Lerman, P. 2006. Styrning av markanvändning och miljön. Stockholm: Ansvarskommitténs skriftserie. Vuorio, T. 2003 Information on Recreation and Tourism in Spatial Planning in the Swedish Mountains - Methods and Need for Knowledge. Blekinge Institute of Technology Licentiate Dissertation Series 2003:03, ETOUR scientific book series V2003:12.

7 Larsson, S. 2014b. What Type of Knowledge Rules Where? Legally Regulated Participation in a Large-Scale Mobile Infrastructure Planning in Sweden. Environment \& Planning C: Government \& Policy. 32(1): 163-183. cf. Larsson, S. 2008. Between Daring and Deliberating $3 G$ as a Sustainability Issue in Swedish Spatial Planning. Blekinge Institute of Technology, Licentiate Dissertation Series No. 2008:02, School of Technoculture, Humanities and Planning.

8 Dir. 2007:184 Tilläggsdirektiv till Miljöprocessutredningen (M 2007:04) [Supplement Directive for environmental process investigation]. 
planning side", including detailed development plans and building permits, or the "regional environmental side", entailing environmental permits. They chose the latter, motivating this stepping away from municipal decision-making power by referring to the municipal comprehensive planning as the appropriate means for the municipalities to influence the environmental permit process and thereby to control wind power development within their local jurisdictions?. The proposal was heavily criticised from the perspective that it undermined the so-called municipal planning monopoly. This led to two compromises: one related to larger wind mills (height over 150 metres; or group stations with mills higher than 120 metres; in both cases height is calculated from the base to the tip of the blades at the highest point), where the local authorities were given what has been termed a "veto" (this is not the legal term, but it has been interpreted as such, and is often called so in the public debate) in that they can approve or in effect deny the giving of the environmental permit without giving any reasons, which in practice amounts to a power of veto. The other was that single windmills smaller than 150 metres high (but above 20 metres) and groups of fewer than 7 mills still require building permit from the municipal authorities and notification in accordance with the Environmental Code. The logic of these two concessions to local authority is difficult to understand given that the object was to streamline permit granting to facilitate a faster development of wind power. Interpretation of the authors of this paper is that there was a belief that technical and economic factors, which had hitherto caused a successive increase in size and generating capacity, would mean an automatic change to the new system, thus making environmental permit granting the dominant route at the regional level.

\subsection{Research purpose and questions}

The purpose of the article is to understand more about the tension between different administrative levels in the Swedish system of environmental governance with regards to wind power. The specific traits of this system to a large extent define the outcome of important challenges related to environmental concerns, spatial planning and public participation, and the system is a complex set of intermingled entities, such as different administrative levels, law, private and public interests, the top-down policy initiatives as well as industrial players in the wind power business. Therefore, the specific research questions are as follows:

1. How can the Swedish wind power development be understood in terms of the different levels of governance, from national to regional and local?

2. What does the so-called municipal veto mean for the Swedish wind power development? In particular, how is the veto right perceived and conceptua-

9 Preparatory legal report SOU 2008:86 Prövning av vindkraft, delbetänkande av Miljöprocessutredningen, Stockholm, p.222. 
lized by involved parties, such as concerned citizens and wind-power companies?

The so-called municipal veto is at the core of the challenges between local planning, regional environmental assessments and national policy - all of which interact to determine Swedish wind power development. At the same time, this example can tell about issues of general interest when it comes to national policymaking that presupposes to local implementation, as well as of the role of law in spatial planning. ${ }^{10}$ The case of wind power deployment in Sweden illustrates more general questions of importance for governance, especially concerning the relationship between regulation of the implementation of national goals and the regulation of local planning.

\section{Tiering and multi-level governance}

Within a doctrine of rationalist planning, the notion of a hierarchical system of decision-making with an increasing level of detail as one moves down to implementation and daily operation is an important assumption. This hierarchical and top-down model of multi-level governance has been long criticised from both theoretical and practical points in the planning literature ${ }^{11}$, political science (a classic is Etzioni ${ }^{12}$ ) and SEA theory ${ }^{13}$. However, it is a mainstay of both EU and national Swedish regulation of Environmental Assessment, which is one of the important tools of environmental integration into spatial planning. It is often termed tiering in the Strategic Environmental Assessment, SEA and literature ${ }^{14}$. The assumption of a tiered system of planning and decision-making is the historical basis for the development of SEA and central to the relationship between the EU directives on EIA and SEA, respectively. Indeed, tiering has been described as the key element of SEA and even one of the major drivers for the development of SEA ${ }^{15}$.

10 Larsson, S. 2014a. Law and Spatial Planning. Socio-legal Perspectives on the Development of Wind Power and $3 G$ Mobile Infrastructures in Sweden, Blekinge Institute of Technology, Dissertation Series, Department of Spatial Planning, Faculty of Engineering.

11 Alexander, E.R. 2000. Rationality Revisited: Planning Paradigms in a Post-Postmodernist Perspective. Journal of Planning Education and Research. 19: 242-256; for an overview, see, e.g. Allmendinger, P. 2009. Planning Theory, second edition, Palgrave Macmillan

12 Etzioni, A. 1967. Mixed-scanning: A 'Third' Approach to Decision-making. Public Administration Review. [Reprinted in: Faludi, A. 1973. A Reader in Planning Theory. Urban and Regional Planning Series. Vol. 5. Oxford: Pergamon Press.]

13 Cherp, A.; Watt, A.; Vinichenko, V. 2007. SEA and Strategy Formation Theories: From Three Ps to Five Ps. Environmental Impact Assessment Review. 27(7): 624-644.

14 Lee, N.; Walsh, F. 1992. Strategic Environmental Assessment: An Overview. Project Appraisal. 7(3): 126-136.

15 Arts, J.; Tomlinson, P.; Voogd, H. 2005. EIA and SEA Tiering - The Missing Link? Position Paper Conference on "International Experience and Perspectives in SEA" International Association of Impact Assessment.26-30 September 2005, Prague. 
Arts et al. ${ }^{16}$ define the concept of tiering as the distinguishing between different levels of planning - policy, plans, programs - that are prepared consecutively and influence each other ${ }^{17}$. Tiering is then "about how the different levels of planning relate to each other"18. The tiered system is assumed to be internally consistent, top-down and in the case of environmental issues based on a scientific, calculating rationality ${ }^{19}$. The higher levels are assumed to set clear limits to the degree of freedom of lower limits, using, for example, binding and quantitative norms in the form of environmental standards and thresholds ${ }^{20}$. In the development of EA, this process was seen as the "foreclosure of options" of lower levels necessitating both a binding strategic planning and the application of SEA ${ }^{21}$. It can thus be argued that while the notion of vertical consistency has weak theoretical foundations and highly varied practical application in existing planning systems, it is, nevertheless, an important component of multi-level governance utilising national goals and objectives and methods of management by objectives. While tiering is essentially an aspect of vertical relationships within government, the concept of multi-level governance, MLG, is also of importance to this discussion. This stresses not only the vertical dimension of government, but also the interdependence between governmental and non-governmental actors, which is the essence of "governance"22. Governance with central directives, goals, or standards and threshold is by its very nature topdown while in theory allowing lower level choice of means of achieving objectives. However, the role of central directives, standards and norms as well as more general national and supranational goals may be to attempt to impose a measure of vertical and top-down consistency rather than assuming it as an inherent characteristic of the system ${ }^{23}$.

16 Arts, J.; Tomlinson, P.; Voogd, H. 2005, supra note 15.

$17 c f$ EC, European Commission. 1999. Manual on Strategic Environmental Assessment of Transport Infrastructure Plans. Drafted by DHV Environment and Infrastructure. DG VII Transport Brussels, p. 16-22.

18 Arts, J. Et al, supra note 14, p. 2.

19 Sager, T. 1994 Communicative Planning Theory, Aldershot: Ashgate. Emmelin, L.; Kleven, T. 1999. A Paradigm of Environmental Bureaucracy? Attitudes, Thought Styles, and World Views in the Norwegian Environmental Administration. NIBR's Pluss Series, p. 5-99.

20 Emmelin, L.; Lerman, P. 2008. Environmental Quality Standards as a Tool in Environmental Governance - The Case of Sweden. In: Schmidt, M., Glasson, J., Emmelin, L., Helbron, H. (Eds.). Standards and Thresholds for Impact Assessment. Springer Verlag.

21 Wathern, P. 1988. An Introductory Guide to EIA. In: Wathern, P. (Ed.). Environmental Impact Assessment. Theory and Practice. London: Unwin Hyman, p. 1-29.

22 cf Appelstrand, M. 2007. Miljömålet i skogsbruket - styrning och frivillighet. Lund Studies in Sociology of Law 26, Lund University. Hajer, M. 2011. Authoritative Governance: Policymaking in the Age of Mediatization. Oxford: Oxford University Press.

Emmelin \& Lerman, supra note 19. 


\section{The Swedish system of environmental governance}

The Swedish system of environmental governance and spatial planning can for the purpose of the present discussion be described as an asymmetrical, three tiered system with two main sets of legislation and "streams" of administration and decision-making. On the one hand, there is the Environmental Code defining processes and substantive goals of environmental governance. On the other hand, planning practice is codified by the Planning and Building Act. The Swedish system of government has three levels: national, regional and local. The regional system with a County Administrative Board is for historical reasons an arm of central government, whereas the local level is based on decision-making in an elected body, the Municipal Government, served by branches of local administration and professionals. Within the two "streams", their relative importance and power are distinctly different. With Sweden's entry into the EU, a further level of governance was introduced. In the case of wind power planning, this added level has several influences, such as through EA directives, goals for renewable energy, etc. ${ }^{24}$.

One aspect of the Swedish spatial planning system is of particular importance from the perspective of tiering and MLG. The municipality has, as already noted above, a monopoly on plan making and there are no higher tier spatial plans made at either national or regional level, which singles Sweden out in a European territorial governance perspective. At the regional level, there is no politically elected body responsible for plan making ${ }^{25}$. The regional arm of the state, the County Administrative Board, does not make plans but oversees municipal plan making, especially with regards to legality, national interests and sector interests (cf COMMIN) ${ }^{26}$.

In this paper, it is the multi-level governance aspect and the relationships between the levels in the two "legal/administrative streams" that is in focus rather than the paradigmatic struggle between them. While the focus here is on the vertical aspect of MLG, it is also important to note the horizontal interaction between the environmental permit system and planning ${ }^{27}$. It is, in this respect, important to note that not only are the relationships between levels in the system different in the two streams, but they are also based on different models of governance rooted

24 Emmelin, L.; Lerman, P. 2006. Styrning av markanvändning och miljön. Stockholm: Ansvarskommitténs skriftserie.

25 There is a long-standing debate on the regional organisation and representation in Sweden. As a test case, two regions, Skåne and V Götaland, have been created from former counties and "parliaments" have been elected. The discussion of organisation here refers to the rest of Sweden, where more or less loose regional organisations based on the municipalities exist and the County Administrative Board is the regional administration. The reform of the regional structure has entered a state of limbo after a proposal by a commission on the regional organisation.

26 COMmon MINdscapes is a EU-financed project concerned with the spatial development in the Baltic.

27 Dühr, S.; Colomb, C.; Nadin, V. 2010. European Spatial Planning and Territorial Cooperation. Routledge. 
in different paradigms and professional cultures ${ }^{28}$. The paradigmatic struggles of different professional cultures, norms and legal administrative "streams" fit well into the concept of MLG, which challenges "the hierarchy fallacy" 29 , i.e. simplistic notions of tiering, and emphasizes that authority is gradually dispersing across sectors and levels ${ }^{30}$. While the concept has been criticised as being "more a metaphor than theory" ${ }^{31}$ and "lacking in a set of testable hypotheses"32, nevertheless, it has proved useful in understanding environmental policy ${ }^{33}$ and is relevant as a characteristic of the structure that the authors of this paper describe.

\subsection{Regulating the relationship of the levels}

In June 2007, The Environmental Process Commission was appointed with the mission to facilitate, coordinate and otherwise make efficient the administration and judicial review of property cases and matters under the Environmental Code and the Planning and Building $\mathrm{Act}^{34}$ In addition, according to the supplementing directive 2007:184, given on December 20, 2007, the committee should also consider the need for amendments related to renewable energy, water activities and national interests under Chapter 3 of the PBA, environmental impact assessments, and coordination and consultation in the review procedure. The Commission was to propose necessary amendments to the Environmental Code, the Planning and Building Act and other relevant statutes. According to the directive, the overall purpose of the mission was to " $[\mathrm{m}]$ ake more efficient the environmental assessment, i.e. to make the trial more quick and easy, without bypassing rule of law, health and environmental protection requirements. In this context, a starting point is that the processing time should be kept as short as possible without hindering the ability to meet the environmental objectives or override the public's right to transparency and participation"35.

Furthermore, the directive says that the "[p]roposals must involve the coordinated management of trial processes and enable a more transparent and temporally shorter

28 Emmelin, L.; Kleven, T. 1999. A Paradigm of Environmental Bureaucracy? Attitudes, Thought Styles, and World Views in the Norwegian Environmental Administration. NIBR's Pluss Series, p. 5-99; Emmelin, L. 2000. Nordisk miljöförvaltnings professionskultur och några aktuella frågeställningar i miljöpolitiken. Tidskrift for Samfunnsforskning. 41(3): 486-517.

29 Emmelin, L. In Press. Reflections on a Dysfunctional SEA-System - The Case of Swedish Spatial Planning. In: Sadler, B., Dusik, J. (Eds.). European and International Experiences of SEA. Earthscan/Routledge.

30 Dühr, S. et al, supra note 26, p.98.

31 Rosamond, B. 2000. Theories of European Integration. New York: St. Martin's Press, p. 11

32 Jordan A. 2001, The European Union: An Evolving System of Multi-Level Governance or Government? 29 Policy and Politics 193, p. 201.

33 Dühr, S. et al, supra note 26.; Naujekaite, J. 2011. The Implementation of the Kyoto Targets in Lithuania from a Perspective of Multilevel Governance. PhD Thesis, Mykolas Romeris University.

34 Dir. 2007:94 Ny instansordning för vissa miljöbalks- och PBL-ärenden samt ett samordnat dömande vid miljödomstolarna och fastighetsdomstolarna. 
and more efficient processing, while the trial is to remain diligent and in accordance with the rule of law"36. In the directive, a clear emphasis was made on efficiency, both in terms of reducing any parallel processing and also by coordinating handling between agencies. Before August 2009, the permit processes for wind power demanded permits from both of the main bodies of law, the PBA and the EC, which led to a need to choose which one was to be given preference. The proposal ${ }^{37}$ and the subsequent governmental bill ${ }^{38}$ chose the regional and environmental path, emphasizing that the comprehensive plan ${ }^{39}$ would be the municipalities' most important instrument for taking part in the wind power development.

This meant that the local municipalities would, to some extent, loose their power over the planning of this particular development, which their representatives were quick to point out. Many commentators to the proposal, including the Swedish Association of Local Authorities and Regions, which is the national association representing all the municipalities, did not share the commission's assessment that it was enough that the examination of large wind power installations be made under the Environmental Code. They claimed that the proposal involved an unacceptable restriction of the municipal plan monopoly ${ }^{40}$.

It is worth noting that in the report from the Environmental Process Commission drafting the preparatory bill there was no proposal to compensate for the restrictions on the right of municipalities to decide on land use. The committee claimed that municipal control over the siting of wind farms would largely be unchanged since the municipal position would continue to be taken into account through the comprehensive plan, and by the municipality's position as a strong referral organization.

The subsequent governmental bill expressed a different assessment of the impact on local self-government. It was claimed that the removal of requirements for building permits and detailed development plans would be compensated with a municipal veto power " $[t]$ o some extent satisfy respondents' submissions on this part and ensuring a high level of municipal influence over the use of land and water" ${ }^{\prime 1}$. This was the only reason given for introducing what amounts to a municipal power of veto. Despite the introduction of the veto, it meant a restriction on local autonomy with regards to planning. However, the restriction in the bill was claimed to be necessary with regards to meeting the goals set in the use of renewable energy, making it very urgent that the trials in the wind power processes become more efficient and simple ${ }^{42}$.

Supra note 8, p. 7

37 Preparatory legal report SOU 2008:86 Prövning av vindkraft, delbetänkande av Miljöprocessutredningen, Stockholm.

39 The comprehensive plan is a mandatory plan covering the entire area of the municipality; it is, however, not legally binding.

40 Supra note 37, p.39.

41 Ibid., p.40

42 Supra note 37, p.49 


\section{Method and materials}

The method for this study is a combination of the following: 1) traditional analysis of the legal documents formulating the Swedish system for environmental governance with regards to wind power, and mostly qualitative analysis and discursive exemplification, along the lines of the literature sociological approach of Burke ${ }^{43}$, 2) analysis of the sample of wind power processes, including consultation documents, and 3) interviews with a handful of key persons, such as two expert judges respectively in the Land and Environment Court (LEC) and the Land and Environment Court of Appeals (LECA - the "supreme" environmental court), regional handling officers assessing turbine applications and the wind power coordinator appointed by the government in order to facilitate the development in Southern Sweden.

The sample consists of 30 wind power processes in the county of Skåne, which is one out of 21 counties in Sweden, and the county that during 2011 had the second most installed effect of wind power and number of wind power turbines of all Swedish counties $^{44}$. The permit process material consists of applications from developers, letters from the public, consultation documents, appeal documents, etc., including information on height, number of turbines, dates, locations, etc. In this study, the type of data that has been of the most interest regards the written documentation from the consultation processes in the permit handling, which is here analysed qualitatively in order to detect concerned individuals' attitudes towards the municipality and the veto process, and more. Legal sources, such as preparatory bills and public legal investigations, have been used in order to depict and analyse the legal development of relevance within the scope of the study. In addition, secondary sources and other relevant studies have been taken into account when applicable.

The legal material has already been mentioned and consists of the explicit legal regulations, such as the Planning and Building Act ${ }^{45}$ and the Environmental Code ${ }^{46}$, but also of the regulation for economic support for wind power planning ${ }^{47}$, the main directive for the wind power commission ${ }^{48}$ and the supplementing directive of most interest to the wind power processes ${ }^{49}$. Further, the most important sources for studying the intentions behind the legal revisions implemented in August 2009, which can stand for the manifest intentions of the law, consist of the proposal that was drafted by the Environmental Process Commission (Miljöprocessutredningen)

Asplund, J. 1979. Teorier om framtiden, Stockholm: Liber Förlag.

45 Plan- och bygglag. That was revised in May 2011, from 1987:10 to 2010:900.

46 Miljöbalk 1998:808.

47 Förordningen (2007:160) om stöd till planeringsinsatser för vindkraft.

48 Dir. 2007:94, Ny instansordning för vissa miljöbalks- och PBL-ärenden samt ett samordnat dömande vid miljödomstolarna och fastighetsdomstolarna. 
in late $2008^{50}$ and the subsequent governmental bill that followed in the spring of $2009^{51}$.

\section{Results}

The legal revisions have been already accounted for in the narrative of this article and may be summed up with two brief concepts: increased efficiency, understood mainly in terms of speed. The preparatory work has emphasized the importance of shortening time from application to decision. This focus on time aspects in planning and decision-making is of interest from a wider planning perspective, which will be returned to in the analysis below. Further, the "municipal veto" that emerged in the governmental bill but was not included in the preceding proposal from the wind power commission is of great interest in terms of power structures and who controls the spatial development.

\subsection{Veto, efficiency and timing}

There have been anecdotal cases in the press regarding cases where the municipalities' answers have arrived late in the permit process, presumably adding to the aspects of uncertainty in the planning. It is simply hard for the applicants to make decisions over investments if the negative decisions arrive at a very late stage in the process.

The County Administration of Skåne, which is the sample region in the study, sent a letter to the Swedish Ministry of Environment regarding the municipal veto in 2010 . According to this letter, the municipalities tend to produce their own background material for their decisions regarding the permits applied for. Furthermore, the municipalities sometimes add conditions as a complement to the delivered opinion, which is not an action prescribed in the law. The County Administration asked for a clarification of the rules regarding what the municipalities may or may not do, and demanded that the time frames for the municipal decisions should be more clearly specified. In 2012, the Swedish Energy Agency (Energimyndigheten) issued a report including the "veto issue" 52 . The report comments upon the so-called municipal veto as problematic in relation to wind power development, arguably because it "has meant that the permit process in many cases has been extended, because it has taken a long time before the local authority has answered. In some cases, the municipal answer has

\section{$50 \quad$ Supra note 9.}

51 Supra note 38, p.146.

52 Statens Energimyndighet 2012. Utvecklingen av tillståndsprocesser för anläggningar som producerar förnybar el och för kraftnät, Redovisning av uppdrag 10 i Regleringsbrevet för Energimyndigheten 2012. Stockholm. 
taken over one year"53. The long delay - as argued in the Energy Agency report - from the municipal side in these cases is caused by the municipalities being in a process of complementing the comprehensive plan with a specific supplement on wind power. The municipalities have in these cases wanted to finish the comprehensive plan process before answering the county administrations regarding wind power projects $^{54}$. This is in the report taken as an indication that the answers will not be as delayed in the future. According to the regional sample of permit processes in Skåne, the majority of questions are asked, however, by the County Administration within one or two months from when the permit application arrives (10 cases - in only 2 cases has the municipality not answered within approximately 3 months, and one with the information about veto missing). This indicates that the municipal involvement occurs fairly early in the process.

\subsection{The veto as perceived by concerned citizens}

In the consultations that are organised at the regional level as a part of the permit handling process, there is in the sample a lot of material on citizens' views on the municipalities' role. Often, it is democratic concerns that are spoken about in the consultations, as an issue directed towards the municipalities rather than at the companies that seek to establish wind power ${ }^{55}$. It seems that the municipality and its representatives often are targeted in the comments even if the process formally is tied to the regional level and the local planning is not the most central aspect controlling the actual wind power establishment.

Another issue often addressed is a fear that the wind power establishment will lead to a depreciation of property values ${ }^{56}$, which is a rather common concern reported in the literature ${ }^{57}$. Much has been written on local opposition to wind turbines and wind farms $\mathrm{s}^{58}$, including for Swedish circumstances ${ }^{59}$.

53 Supra note 50, p. 23.

54 Ibid.

55 As in Eslöv-Hörby/Söderto-Mossarp (extensive protest list), Hässleholm Ignaberga-Attarp, Kristianstad Maltesholm, Sjöbo-Hårderup-Alestad, Sjöbo-Klamby.

56 As in Eslöv Örtofta, Sjöbo-Klamby, Ystad- Eriksfält/Örum.

57 Agterbosch, S.; Glasbergen, P.; Vermeulen, W.J.V. 2007. Social Barriers in Wind Power Implementation in The Netherlands: Perceptions of Wind Power Entrepreneurs and Local Civil Servants of Institutional and Social Conditions in Realizing Wind Power Projects. Renewable and Sustainable Energy Reviews. 11: 1025-1055.

58 Devine-Wright, P. 2005 Beyond NIMBYism: Towards an Integrated Framework for Understanding Public Perception of Wind Energy. Wind Energy. 8: 125-139.; Petrova, M.A. 2013. NIMBYism Revisited: Public Acceptance of Wind Energy in the United States. WIREs Clim Change. 4: 575-601.; Wolsink, M. 2000. Wind Power and the NIMBY-myth: Institutional Capacity and the Limited Significance of Public Support. Renewable Energy. 21: 49-64.

59 Ek, K. 2005. Public and Private Attitudes towards "Green" Electricity: The Case of Swedish Wind Power. Energy Policy. 33: 1677-1689. 


\subsection{The veto as perceived by wind-power companies}

The "veto" rule that was introduced as a compromise to satisfy the advocates for municipal influence in wind power issues and the restrictions that are nevertheless meant for local self-government were issued because they were claimed to be "very important position to the handling of wind power cases simpler and more efficient"60. Several stakeholders have, however, voiced concerns over the veto compromise. It has, according to a pro-wind power NGO, led to "a completely unpredictable permit process" ${ }^{\prime \prime}$, and the Swedish Energy Agency [Energimyndigheten] in a report from 2012 stated that the municipal answers sometimes are unclear or even missing, leading to a delay in the permit handling processes ${ }^{62}$. The Svensk Vindenergi report states that "at least 380 planned turbines [...] have already been stopped by the veto"63. The problem, as they see it, lies in the following:

A municipality that has a negative attitude towards wind power, is hesitant or uninterested, may simply fail to address the case and thus in practice prohibit the installation. The municipality does not even have to justify its position in any way.

Of particular interest for this study is the fact that 16 out of 21 wind power developers think that, all in all, it has become more difficult to get permission for wind power turbines after the legal revisions made in August 2009. Only 2 out of 21 think that it has become easier ${ }^{64}$.

The informants confirm that many wind power companies prefer the municipal permit option. The expert judge in the Land and Environment Court of Appeals stated that the "regulation leads to a large number of wind turbines that are $149 \mathrm{~m}$ high, i.e. below the limit set for the regional environmental trial". That is, the operators prefer the municipal trial before the regional environmental trial that includes the veto regulation. The regional handling official, representing the receiver of environmental permit applications at the regional level, also confirms this.

The pro-wind energy NGO also demands that the municipal veto ought to be removed, which they wish to diminish to something they express as that the municipal opinion should "carry weight" and it should clarify the municipal position on the wind-power project. The NGO wishes for the return of the municipal building permit if the veto cannot be remodelled. This is a clear critique of the path chosen by the Environmental Process Commission and the amendment to the process ${ }^{65}$.

60 Supra note 37, p.49.

61 Svensk Vindenergi 2010. Kommunernas användning av vetot mot vindkraft. Enkätundersökning bland Svensk Vindenergis medlemsföretag, p.2.

62 Supra note 49, p. 23.

63 Supra note 58, p. 2.

64 Ibid., p. 11-12.

65 Supra note 58, p. 2-3. 


\section{Analysis: Levels of governance and outcomes of law}

The following section addresses the two specific research questions outlined in the introduction of the article before a briefer section making suggestions on alternative approaches.

\subsection{Levels of governance in the Swedish wind power development}

The tiering of the Swedish system creates an interesting imbalance. This is because what we call the "two streams of administration" operating according to different logics. Moving the focus of the processes of wind power permit handling from the governance of the local planning system to the environmental government system has most likely caused changes in principle of how wind power is seen in a wider context.

The planning system operates with a hierarchy of local plans from the comprehensive, indicative plans covering the entire territory of the municipality, to binding detailed development plans and building permits. The object of this tiered system is to produce a spatial pattern of land use that is seen as desirable from several perspectives. In a building permit process the municipal planning system is thus not only considering the rights of those formal stakeholders defined by economic interest and property directly involved, but also how the individual wind power plant or farm fits into a system and vision of development of the area and the municipality. In the comprehensive planning, especially the wind power supplementary plans, the municipality can thus weigh technical suitability for wind power generation against projections of future growth, conservation and visual landscape impacts and fuzzy concepts, such as sustainable development as interpreted by the municipality. The tiering at higher levels is, however, as pointed out, weak. The national wind power development interest and goals are manifest in the designated areas of national interest, which the Swedish Energy Agency has defined on wind power potential alone. No regional spatial planning exists in Sweden. As noted by Haughton et al. ${ }^{66}$, local planning authorities in other countries find it very easy to ignore the wider context in which they operate. The regional administration's role in spatial planning is in Sweden only to oversee if and how the municipality takes this sectorial, national interest into account in the comprehensive plan.

The lowest level of the environmental permit system is the regional arm of government. However, the extent to which regional aspects of environment or renewable energy is considered seems negligible in the present cases. The environmental management side basically tests the permissibility of any given application against formal criteria, such as noise and disturbance from moving

66 Haughton, G.; Allmendinger, P.; Counsell, D.; Vigar, G. 2010. The New Spatial Planning: Territorial Management with Soft Spaces and Fuzzy Boundaries. Routledge, p. 10. 
shadows and amenity loss. It is basically concerned with weighing the rights and interests of the applicant against the rights and interests of the affected property owners in the vicinity.

The Swedish system of environmental governance, also in the case of wind power, is complex and relates not only to a number of levels, but also to the industrial initiatives as well as citizen attitudes and conceptions. The legal revision made in 2009 was substantial and has been criticised for being too legally dogmatic, that is, basing proposals not on systematic knowledge of, for example, why people appeal wind power permits, but on a combination of anecdotal evidence, of the type that has been quoted above, and legal cases and assumptions made on detailed intra-legal reflections ${ }^{67}$. As a consequence, the legal framework was changed without any reliable assurance that the revisions would actually fulfil their purpose. The proposal suggested a handling process utilising a regionally based environmental judgment rather than the municipal planning approach, which has to be seen in the light of Sweden's strong local planning tradition. This explains much of the critique that the proposal received and the political compromise, which means that the municipalities lost much of the planning responsibilities, but a right remained to approve or disapprove large-scale wind power localisations within the municipality, even though the actual process was placed at another level and in another "decision stream".

\subsection{The so-called municipal veto}

This article deals with issues of hierarchy in the decision-making over wind power planning and permit handling in Sweden. One of the most important issues of interest in this context is the relationship between the regional level and the local, municipal level. There are several reasons for this, but the fact that most permit handling is done at the regional level while the municipality has to agree or disagree to the decision, without giving any reasons, often referred to as the "municipal veto", forms a setting of interest here. It expresses some sort of compromise between the powers at different levels in the environmental permit system and the planning system, leading to empirical outcomes decisive for wind power development in Sweden. An inherent problem with present policy objectives is that they are not based on any assessment at the local level of what can reasonably be achieved within the framework of the

67 Larsson, S. 2009. Problematisering av vindkraftens regelverk. En pilotstudie. Forskningsrapport Nr. 2009:04, Rapport nr 7 från MiSt-programmet, Blekinge Tekniska Högskola, ISSN 11031581.; Larsson, S. 2011b. Vindkraftsutbyggnaden - Vem bestämmer och baserat på vilken kunskap? In: Mossberg (ed.). Buller i blåsväder - texter om ljud från vindkraftverk. Skrifter från Ljudmiljöcentrum vid Lunds universitet Rapport nr 11; Larsson, S. and Emmelin, L. 2009 Implementing National Policy and Local Planning - Swedish wind power development and third generation mobile phone system as cases, conference paper for International Academic Group On Planning, Law And Property Rights Third Conference in Aalborg, Denmark, 11-13 February 2009. 
planning system. It is clear from the legislative history of the revision that the starting point of the reform was not to consider first the realism of an objective in relation to the preferences in the system, which poses problems of tiering. The stated purpose of these changes was to streamline wind power development by eliminating parallel trials, not ostensibly to reduce the municipal influence in questions regarding the use of municipal land.

The object of switching the permit process away from municipal spatial planning was to create a process that was more efficient by abolishing double permit processes in the hope of speeding up the granting of permits ${ }^{68}$. From this perspective, the introduction of the "municipal veto" would seem counterproductive. If the trend towards larger wind mills does not continue, then the split at a height of 150 metres would also be counterproductive since the parallel permit processes will continue to be common.

From the perspective of effectiveness, the situation is complex. Whether the parallel process is seen as producing, more or less legitimate decisions will depend on stakeholder perspectives. However, with respect to weighing of interests, the environmental permit system and the spatial planning system differ in basic logic, as noted above. If there is a difference in the actual outcomes depends both on the quality of comprehensive planning and the degree to which the environmental permit system takes municipal plans into consideration.

\subsection{Suggestions for legal and administrative reform}

In the present analysis, a functional multi-level governance (MLG) system for wind power would assume a tiered planning system with a regional planning level rather than the present regional state agency overseeing the municipal level. Furthermore, it would assume a higher average quality of spatial planning and a horizontal integration of planning and the environmental permit system than it can be seen at present. An alternative to the present uneasy double command system would be to hand back the permit giving to the planning system and ensure an efficient and effective appeals system. However, this would seem to run contrary to the present narrow focus on efficiency measured simply as time from application to decision, or as noted for the Canadian permit system ${ }^{69}$ : the trend is towards a system that can "get quickly to yes". This is an expression of sector interests and private developers priorities combined with an unrealistic view of the quality of their planning as shown, for example, for infrastructure ${ }^{70}$ or the naive belief that good intentions preclude unwanted or unexpected side effects, making environmental

69 Bram Noble, Seminar at Swedish EIA-centre 2009, SLU, Uppsala.

70 Flyvbjerg, B.; Bruzelius, N.; Rothengatter, W. 2003. Megaprojects and Risk: An Anatomy of Ambition. Cambridge: Cambridge University Press. 
assessment unnecessary ${ }^{71}$. It hardly provides for an effective assessment and permit system from a wider environmental perspective. As noted by Sager ${ }^{72}$, one important role of a permit system is to put a brake on speed-blinded sector authorities and entrepreneurs.

\section{Conclusions}

The legal preparatory works for the legal changes in the Swedish wind power permit process speak clearly about the manifest functions that the revisions are intended for. The changes wrought in the planning and permit processes for wind power are not only specific to the Swedish context, but they also illustrate more general issues in multi-level governance. They must, however, also be seen within a framework of pressures to make planning and permit processes more efficient, which is a component of the planning debate on the political agenda in most European countries $^{73}$.

The results indicate that different parties perceive the municipal veto differently. Interestingly enough, the concerned citizens tend to want municipalities to take a bigger role in the process, even when the process is mainly located at the regional level. The wind-power companies tend to regard the veto as an instrument increasing uncertainty and make it harder to foresee the outcome of the permit processes. Wind power, as with many national policies that have clear local environmental and spatial implications when implemented, is in essence a different issue at different levels. People may agree upon the need for renewable energy as a general, abstract goal, but not necessarily agree that the actual wind turbines should affect their local landscape. In addition, the results indicate that the industry sees the "veto" as leading to problematic uncertainty in the process at the regional level, and therefore, prefer to keep the applications at a level that entitles them to use the municipal handling system - which is determined by height and number of turbines - which is a consequence opposite to what the legal commission aimed for when revising the legal system.

The so-called municipal veto seems to the authors of the paper to be an unfortunate compromise between two systems. Tentatively, a planning system as the first order system with the environmental permit system as the first recourse for appeal would be favoured. The authors base this on the normative standpoint that a

71 Emmelin, L., supra note 28.

72 Sager, T. 2001. A Planning Theory Perspective on the EIA. In: Hilding-Rydevik, T. (Ed.). EIA, Large Development Projects and Decision-making in the Nordic Countries. Nordregio Report, 2001, p. 6.

73 Zonneveld, W.; Evers, D. 2014. Dutch National Spatial Planning at the End of an Era. In: Mario Reimer, M., Panagiotis, G., Blotevogel, H.H. (Eds.). Spatial Planning Systems and Practices in Europe: A Comparative Perspective on Continuity and Changes. Routledge. 
planned development rather than an ad how permit and actor based system would be preferable but being very aware of the actual shortcomings of the spatial planning system, including the lack of a regional spatial arena.

\section{References}

Agterbosch, S.; Glasbergen, P.; Vermeulen, W.J.V. 2007. Social Barriers in Wind Power Implementation in The Netherlands: Perceptions of Wind Power Entrepreneurs and Local Civil Servants of Institutional and Social Conditions in Realizing Wind Power Projects. Renewable and Sustainable Energy Reviews. 11: 1025-1055.

Alexander, E.R. 2000. Rationality Revisited: Planning Paradigms in a Post-Postmodernist Perspective. Journal of Planning Education and Research. 19: 242-256.

Allmendinger, P. 2009. Planning Theory, second edition, Palgrave Macmillan.

Appelstrand, M. 2007. Miljömålet i skogsbruket - styrning och frivillighet. Lund Studies in Sociology of Law 26, Lund University.

Arts, J.; Tomlinson, P.; Voogd, H. 2005. EIA and SEA Tiering - The Missing Link? Position Paper Conference on "International Experience and Perspectives in SEA" International Association of Impact Assessment.26-30 September 2005, Prague.

Asplund, J. 1979. Teorier om framtiden, Stockholm: Liber Förlag.

Bell, D.; Gray, T.; Haggett, C. 2005. Policy, Participation and Social Gap in Wind Farm Siting Decisions. Environmental Politics. 14: 4, 460-477.

Bergek, A.; Jacobsson, S. 2003. The Emergence of a Growth Industry: A Comparative Analysis of the German, Dutch and Swedish Wind Turbine Industries. In: Metcalfe, J.S., Cantner,
U. (Eds.). Change, Transformation and Development. Physica-Verlag, Heidelberg, p. 197-227.

Cherp, A.; Watt, A.; Vinichenko, V. 2007. SEA and Strategy Formation Theories: From Three Ps to Five Ps. Environmental Impact Assessment Review. 27(7): 624-644.

Devine-Wright, P. 2005 Beyond NIMBYism: Towards an Integrated Framework for Understanding Public Perception of Wind Energy. Wind Energy. 8: 125-139.

Dir. 2007:94, Ny instansordning för vissa miljöbalks- och PBLärenden samt ett samordnat dömande vid miljödomstolarna och fastighetsdomstolarna.

Directive 2009/28/EC of the European Parliament and of the Council of 23 April 2009 on the promotion of the use of energy from renewable sources and amending and subsequent repealing Directives 2001/77/EC and 2003/30/ EC.

Dühr, S.; Colomb, C.; Nadin, V. 2010. European Spatial Planning and Territorial Cooperation. Routledge.

EC, European Commission. 1999. Manual on Strategic Environmental Assessment of Transport Infrastructure Plans. Drafted by DHV Environment and Infrastructure. DG VII Transport Brussels.

Ek, K. 2005. Public and Private Attitudes towards "Green" Electricity: The Case of Swedish Wind Power. Energy Policy. 33: 1677-1689. 
Emmelin, L. In Press. Reflections on a Dysfunctional SEA-System - The Case of Swedish Spatial Planning. In: Sadler, B., Dusik, J. (Eds.). European and International Experiences of SEA. Earthscan/Routledge.

Emmelin, L. 2000. Nordisk miljöförvaltnings professionskultur och några aktuella frågeställningar i miljöpolitiken. Tidskrift for Samfunnsforskning. 41(3): 486-517.

Emmelin, L.; Kleven, T. 1999. A Paradigm of Environmental Bureaucracy? Attitudes, Thought Styles, and World Views in the Norwegian Environmental Administration. NIBR's Pluss Series, p. 5-99.

Emmelin, L.; Lerman, P. 2008. Environmental Quality Standards as a Tool in Environmental Governance The Case of Sweden. In: Schmidt, M., Glasson, J., Emmelin, L., Helbron, H. (Eds.). Standards and Thresholds for Impact Assessment. Springer Verlag.

Emmelin, L.; Lerman, P. 2006. Styrning av markanvändning och miljön. Stockholm: Ansvarskommitténs skriftserie.

Etzioni, A. 1967. Mixed-scanning: A 'Third' Approach to Decision-making. Public Administration Review. [Reprinted in: Faludi, A. 1973. A Reader in Planning Theory. Urban and Regional Planning Series. Vol. 5. Oxford: Pergamon Press.]

Flyvbjerg, B.; Bruzelius, N.; Rothengatter, W. 2003. Megaprojects and Risk: An Anatomy of Ambition. Cambridge: Cambridge University Press.

Hajer, M. 2011. Authoritative Governance: Policy-making in the Age of Mediatization. Oxford: Oxford University Press.

Haughton, G.; Allmendinger, P.; Counsell, D.; Vigar, G. 2010. The New Spatial Planning: Territorial Management with Soft Spaces and Fuzzy Boundaries. Routledge.

Jobert, A.; Laborgne, P.; Mimler, S. 2007. Local Acceptance of Wind Energy: Factors of Success Identified in French and German Case Studies. Energy Policy. 35: 2751-2760.

Jordan A. 2001, The European Union: An Evolving System of Multi-Level Governance or Government? 29 Policy and Politics 193.

Khan, J. 2003. Wind Power Planning in Three Swedish Municipalities. Journal of Environmental Planning and Management. 46(4): 563-581.

Larsson, S. 2014a. Law and Spatial Planning. Socio-legal Perspectives on the Development of Wind Power and $3 G$ Mobile Infrastructures in Sweden, Blekinge Institute of Technology, Dissertation Series, Department of Spatial Planning, Faculty of Engineering.

Larsson, S. 2014b. What Type of Knowledge Rules Where? Legally Regulated Participation in a LargeScale Mobile Infrastructure Planning in Sweden. Environment \& Planning C: Government \& Policy. 32(1): 163-183.

Larsson, S. 2013. On Legal Complexity: Between Law in Books and Planning in Practice. In: Baier, M. Social and Legal Norms. Towards a Socio-legal Understanding of Normativity. Ashgate Publishing.

Larsson, S. 2011a. Metaphors and Norms. Understanding Copyright Law in a Digital Society. PhD Thesis, Lund Studies in Sociology of Law, Lund University.

Larsson, S. 2011b. Vindkraftsutbyggnaden - Vem bestämmer och baserat på vilken kunskap? In: Mossberg (ed.). Buller i blåsväder - texter om liud från vindkraftverk. Skrifter 
från Ljudmiljöcentrum vid Lunds universitet Rapport nr 11.

Larsson, S. 2009. Problematisering av vindkraftens regelverk. En pilotstudie. Forskningsrapport Nr. 2009:04, Rapport nr 7 från MiSt-programmet, Blekinge Tekniska Högskola, ISSN 1103-1581.

Larsson, S. 2008. Between Daring and Deliberating - 3G as a Sustainability Issue in Swedish Spatial Planning. Blekinge Institute of Technology, Licentiate Dissertation Series No. 2008:02, School of Technoculture, Humanities and Planning.

Larsson, S. and Emmelin, L. 2009 Implementing National Policy and Local Planning - Swedish wind power development and third generation mobile phone system as cases, conference paper for International Academic Group On Planning, Law And Property Rights Third Conference in Aalborg, Denmark, 11-13 February 2009.

Lee, N.; Walsh, F. 1992. Strategic Environmental Assessment: An Overview. Project Appraisal. 7(3): 126136.

Länsstyrelsen i Skåne län. 1 July, 2010. Skrivelse angående det kommunala vetot enligt 16 kap $4 \$$ miljöbalken.

Marks, G.; Hooghe, L. 2004. Contrasting Visions of Multi-Level Governance. In: Bache \& Flinders (Eds.). MultiLevel Governance. Oxford: Oxford University Press.

Michanek, G.; Söderholm, P. 2006. Medvind i uppförsbacke. En studie av den svenska vindkraftspolitiken. Report to the Expert Group for Environmental Studies, Swedish Ministry of Finance, Stockholm.

Naujèkaite, J. 2011. The Implementation of the Kyoto Targets in Lithuania from a Perspective of Multilevel Governance.
$\mathrm{PhD}$ Thesis, Mykolas Romeris University.

Newig, J.; Fritsch, O. 2009. Environmental Governance: Participatory, Multilevel - and Effective? Environmental Policy and Governance. 19(3): 197-214. Petrova, M.A. 2013. NIMBYism Revisited: Public Acceptance of Wind Energy in the United States. WIREs Clim Change. 4: 575-601.

Prop. 2008/09: 146, Prövning av vindkraft, Miljödepartementet.

Preparatory legal report SOU 2008:86 Prövning av vindkraft, delbetänkande av Miljöprocessutredningen, Stockholm.

Ramböll 2011. Genomförandetider och framtida resursbehov för projekt med miljöpåverkan. Stockholm.

Rosamond, B. 2000. Theories of European Integration. New York: St. Martin's Press.

Sager, T. 2001. A Planning Theory Perspective on the EIA. In: HildingRydevik, T. (Ed.). EIA, Large Development Projects and Decisionmaking in the Nordic Countries. Nordregio Report, 2001, p. 6.

Sager, T. 1994 Communicative Planning Theory, Aldershot: Ashgate.

Statens Energimyndighet 2012. Vindkraftsstatistik 2011. ES 2012:02.

Statens Energimyndighet 2012. Utvecklingen av tillståndsprocesser för anläggningar som producerar förnybar el och för kraftnät, Redovisning av uppdrag $10 \quad i$ Regleringsbrevet för Energimyndigheten 2012. Stockholm.

Svensk Vindenergi 2010. Kommunernas användning av vetot mot vindkraft. Enkätundersökning bland Svensk Vindenergis medlemsföretag.

Toke, D.; Breukers, S.; Wolsink, M. 2008. Wind Power Deployment Outcomes: How Can We Account for the Differences? Renewable and 
Sustainable Energy Reviews. 12: 11291147.

Vuorio, T. 2003 Information on Recreation and Tourism in Spatial Planning in the Swedish Mountains - Methods and Need for Knowledge. Blekinge Institute of Technology Licentiate Dissertation Series 2003:03, ETOUR scientific book series V2003:12.

Wathern, P. 1988. An Introductory Guide to EIA. In: Wathern, P. (Ed.). Environmental Impact Assessment. Theory and Practice. London: Unwin Hyman, p. 1-29.

Wolsink, M. 2000. Wind Power and the NIMBY-myth: Institutional Capacity and the Limited Significance of Public Support. Renewable Energy. 21: 49-64. Zonneveld, W.; Evers, D. 2014. Dutch National Spatial Planning at the End of an Era. In: Mario Reimer, M., Panagiotis, G., Blotevogel, H.H. (Eds.). Spatial Planning Systems and Practices in Europe: A Comparative Perspective on Continuity and Changes. Routledge.

Åstrand, K.; Neij, L. 2006. An Assessment of Governmental Wind Power Programmes in Sweden - Using a Systems Approach. Energy Policy. 34: 277-296.

\title{
DAUGIAPAKOPIS APLINKOSAUGOS VALDYMAS - VĖJO JÉGAINIŲ PLĖTRA ŠVEDIJOJE
}

\author{
Stefan Larsson, Lars Emmelin, Sandra Vindelstam \\ Lundo universitetas, Blekingo technologijos universitetas, Švedija
}

Santrauka. Švedijoje vejjo energetikos vystymas nacionalinejje politikoje yra ypač akcentuojamas, tačiau leidimu statyti véjo jègaines išdavimas labiau priklauso nuo vietines valdžios. Teisès aktai ịpareigoja greičiau išduoti leidimus pirmiausia atsižvelgiant i regioninius aplinkosaugos procesus ir tik tada i vietiniu savivaldybiu planavimo dokumentus. Tradiciškai Švedijoje savivaldybès turi daugiau galiu žemès planavimo procesuose ir dèl to dažnai tai apibüdinama kaip „savivaldybiu planavimo monopolis“. Dabar yra numatyti teisés aktai, kuriais remiantis ši monopolį bus galima ǐskaidyti. Šiame darbe tiriama savivaldybiu veto teise, kompromisai tarp savivaldos ir poreikio vystyti vejo energetiką. Darbe išanalizuota 30 regioninių leidimu, taip pat atliktos ribotos teisèju ir regionu pareigūnų, atsakingu už vejo jégaines, apklausos. Rezultatai parodè, kad vejo jégainiu pramonés atstovai veto teisę laiko pagrindine problema šiame procese regioniniu mastu. Taip pat turi büti funkciju pasidalijimas tarp regiono ir vietos savivaldos.

Reikšminiai žodžiai: vèjo jëgainès, erdvinis planavimas, teisès aktai, sąsajos, daugiapakopis valdymas, savivaldos veto teise.

Stefan Larsson, Lundo universiteto Interneto instituto (LUii) Darbo, technologiju ir socialinių pokyčių centro tyrimų direktorius. Mokslinių tyrimų kryptys: teisè ir edvinis planavimas, skaitmeninès technologijos ir socialiniai pokyčiai. 
Stefan Larsson, Lund University, Lund University Internet Institute (LUii), Centre for Work, Technology and Social Change, Researcher and Director of LUii. Research Interests: Law and Spatial Planning, Digital Technology and Social Change, Metaphors and Law.

Lars Emmelin, Blekingo technologijos instituto Švedijos planavimo mokyklos profesorius emeritas. Mokslinių tyrimų kryptys: erdvinis planavimas ir valdymas, aplinkos vertinimas, rekreacijos ir turizmo planavimas.

Lars Emmelin, Blekinge Institute of Technology, The Swedish School of Planning, Professor emeritus. Research Interests: Spatial Planning and Environmental Governance, Environmental Assessment, Planning for Outdoor Recreation and Tourism.

Sandra Vindelstam, Lundo universiteto Interneto instituto (LUii) Darbo, technologijų ir socialinių pokyčių centro tyrimų asistente. Mokslinių tyrimų kryptys: erdvinis planavimas, kraštovaizdžio architektūra, vejjo energetikos planavimas.

Sandra Vindelstam, Lund University, Lund University Internet Institute (LUii), Centre for Work, Technology and Social Change, Research assistant. Research interests: spatial planning, landscape architecture and wind power planning. 